\title{
In Focus
Spotlight on the September 15 Issue
}

Robert A. Gross, MD, PhD, FAAN

Editor-in-Chief, Neurology ${ }^{\circledR}$

\section{Notable in Neurology}

This issue features an article investigating cerebral microbleeds and postthrombolysis intracerebral hemorrhage risk and another on the development and validation of a simplified Stroke-Thrombolytic Predictive Instrument. Another featured article focuses on the clinical relevance of voltage-gated potassium channel-complex antibodies in children.

\section{ARTICLES}

\section{Recurrent vascular events in lacunar stroke patients with metabolic syndrome and/or diabetes}

This study enrolled 3,020 patients with lacunar strokes. Metabolic syndrome and diabetes mellitus were comorbid conditions in lacunar stroke patients and were associated with stroke recurrence. In patients with lacunar infarcts, a vigilant approach to prevention of diabetes mellitus in those with metabolic syndrome could be a strategy for reducing recurrent strokes.

See p. 935

\section{Perampanel for tonic-clonic seizures in idiopathic generalized epilepsy: A randomized trial OPEN $\mathbb{D}$ ] The number of antiepileptic drugs available to treat primary generalized tonic-clonic seizures is limited. Patients were independently reviewed to ensure diagnosis was confirmed. The seizure-free rate was $30.9 \%$ for perampanel vs $12.3 \%$ for the control group. In patients with idiopathic generalized epilepsy, adjunctive perampanel was well tolerated and improved control of drug-resistant primary generalized tonic-clonic seizures.}

See p. 950

\section{Salivary cortisol, brain volumes, and cognition in community-dwelling elderly without dementia

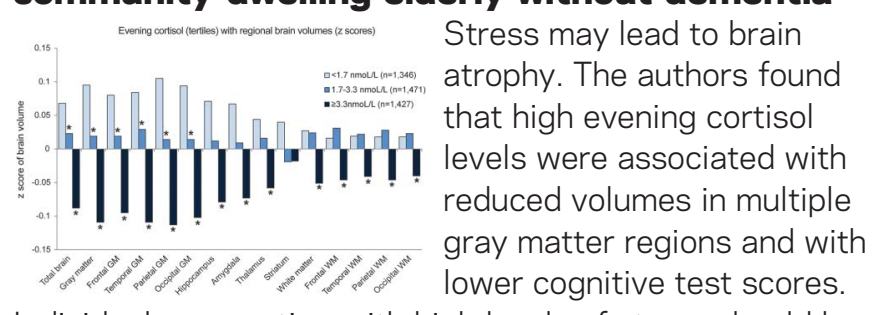

Individuals presenting with high levels of stress should be monitored for cognitive changes.

See p. 976

\section{Temporal course and pathologic basis of unawareness of memory loss in dementia}

In a longitudinal clinical-pathologic study of older persons who were cognitively healthy at enrollment, awareness of memory impairment began to decline about 2-3 years before dementia onset. Unawareness of memory impairment was associated with postmortem evidence of TDP-43 pathology, tangles, and gross cerebral infarcts.

\section{See p. 984}

NB: "Determinants of burnout of neurology trainees in Attica, Greece," see p. e81. To check out other Resident \& Fellow Residency Training submissions, point your browser to Neurology.org and click on the link to the Resident \& Fellow Section. At the end of the issue, check out the Clinical/Scientific Note discussing disseminated cryptococcosis in a patient with multiple sclerosis treated with fingolimod. This week also includes a Clinical Implications of Neuroscience Research article titled "Habenula: Recently recognized functions and potential clinical relevance." 


\title{
Neurology
}

\author{
Spotlight on the September 15 Issue \\ Robert A. Gross \\ Neurology 2015;85;923 \\ DOI 10.1212/WNL.0000000000001920
}

This information is current as of September 14, 2015

\section{Updated Information \&}

Services

Permissions \& Licensing

Reprints including high resolution figures, can be found at: http://n.neurology.org/content/85/11/923.full

Information about reproducing this article in parts (figures,tables) or in its entirety can be found online at:

http://www.neurology.org/about/about_the_journal\#permissions

Information about ordering reprints can be found online:

http://n.neurology.org/subscribers/advertise

Neurology ${ }^{\circledR}$ is the official journal of the American Academy of Neurology. Published continuously since 1951, it is now a weekly with 48 issues per year. Copyright @ 2015 American Academy of Neurology. All rights reserved. Print ISSN: 0028-3878. Online ISSN: 1526-632X.

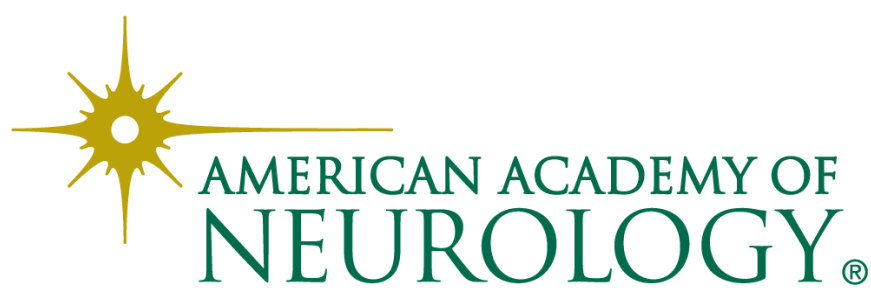

